\title{
R248W Mutations in p53 Gene are Rare among Indian Patients with Head-and-Neck Cancer
}

\begin{abstract}
Aim: Cancer is one of the curses to humankind, decades of research in eradicating the disease from the society is proven difficult. Close interaction between clinicians and scientists helps us to translate clinical observations into molecular mechanism of the disease. The Cancer Genome Atlas data suggest that genetic alterations in $p 53$ gene play a crucial role in head-and-neck squamous cell carcinoma (HNSCC) tumorigenesis. Understanding p53 aberrations and their impact on other cellular activities can help with the design of new, more effective therapeutic strategy that target p53 mutation-bearing HNSCC, thereby producing a personalized medicine approach for the disease. Materials and Methods: In an effort to identify the role of R248W mutation of $p 53$ gene in HNSCC patients of Indian origin, tumor samples were collected from 55 patients $(n=55)$, and polymerase chain reaction-restriction fragment length polymorphism technique was used to screen for the mutation using genomic DNA isolated from the tumors. Results: The results reveal that except for one patient (heterozygous), all the patients were negative for the mutation. Conclusion: These results suggest that p53 R248W mutations are less prevalent in HNSCC Indian patients.
\end{abstract}

Keywords: Head-and-neck cancer, mutation, p53, polymerase chain reaction-restriction fragment length polymorphism

\section{Introduction}

Head-and-neck squamous cell carcinoma (HNSCC), a major form of head-and-neck cancer, is an important clinical challenge in oncology and is the sixth most common cancer in the world today. ${ }^{[1]}$ More than 600,000 new head and neck cancer cases are diagnosed annually in the world, with about 350,000 deaths. ${ }^{[2]}$ The Cancer Genome Atlas data suggest that genetic alterations in p53 gene play a crucial role in HNSCC tumorigenesis. ${ }^{[3]}$ Identification of various gene mutations in cancer patients and relating their impact on cancer progression and recurrence will give us an insight into the role played by these mutations in cancer.

The $p 53$ gene product is involved in regulating several key events in the cell that are essential for cell growth and suppression of malignancy. Thus, mutation in p53 induces malignancy. ${ }^{[4]}$ When DNA gets damaged, wild-type p53 protein accumulates and stops replication to repair

This is an open access journal, and articles are distributed under the terms of the Creative Commons Attribution-NonCommercial-ShareAlike 4.0 License, which allows others to remix, tweak, and build upon the work non-commercially, as long as appropriate credit is given and the new creations are licensed under the identical terms.

For reprints contact: WKHLRPMedknow_reprints@wolterskluwer.com the DNA. This is followed by triggering specific cell cycle arrest in the G1/S phase. In case of tumor cells bearing mutated $\mathrm{p} 53$, this cell cycle arrest is not induced, which corresponds to an increase in various somatic mutations in cells that help the progression of cancer. ${ }^{[5]}$ Inactivation of tumor suppressor gene p53 plays a key role in cancer development. The $p 53$ gene is frequently lost or mutated in several kinds of tumors, including the colon, lung, breast, brain, ovary, and esophagus implicating p53 as an important tumor suppressor gene. ${ }^{[6]}$ In head-and-neck cancer, alterations of p53 gene have been implicated at a high incidence of the disease. ${ }^{[7]}$

In several forms of cancer, p53 is mutated and codon 248 is one of the hot spot regions which represents $60 \%$ of known p53 mutations. ${ }^{[8]}$ In HNSCC also, $75 \%$ to $85 \%$ of human papillomavirus-negative patients possess mutations in TP53 and most of the mutations are frequently observed within the DNA binding domain of the p53 protein. ${ }^{[9]}$ All p53 mutations described in HNSCC occur in highly conserved regions between exon 5 and $8 .^{[10]}$ In head-and-neck cancer, p53 mutations are

\footnotetext{
How to cite this article: Gauthaman A, Moorthy A. $\mathrm{R} 248 \mathrm{~W}$ mutations in $p 53$ gene are rare among Indian patients with head-and-neck cancer. Indian J Med Paediatr Oncol 2020;41:519-22.
}

\section{Ashna Gauthaman, Anbalagan Moorthy}

Department of Integrative Biology, School of Bio-Sciences and Technology, Vellore Institute of Technology, Vellore, Tamil Nadu, India

Submitted: 13-Dec-2019

Revised: 25-Jun-2020

Accepted: 29-Jun-2020

Published: 29-Aug-2020

Address for correspondence:

Dr. Anbalagan Moorthy,

Department of Integrative

Biology, School of Bio-Sciences and Technology, Vellore

Institute of Technology,

Vellore - 632 014, Tamil Nadu,

India.

E-mail: anbalagan.m@vit.ac.in

Access this article online

Website: www.ijmpo.org

DOI: 10.4103/ijmpo.ijmpo_248_19

Quick Response Code:

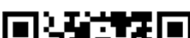


significantly associated with short survival rate and often resistant to standard treatments including radiotherapy and chemotherapy. This indicates that for head-and-neck cancer patients, p53 mutations can be used as a prognostic biomarker. In p53 protein, since codon 248 is one of the hot spot mutations observed in several forms of cancer and there is no report available on the prevalence of this mutation in Indian HNSCC patients, this study was carried out.

\section{Materials and Methods}

\section{Patients and specimens}

Tumor samples used in this study were surgically excised from 55 head-and-neck cancer patients at Apollo hospital, Chennai, India. After resection, the tumors were snap-frozen and then transported to VIT University, Vellore. All patients were followed up and the data concerning cancer recurrence and patient survival were collected. We obtained informed consent from all the individuals who participated in the study as well as approval from the institute's human ethical committee (IEC/IRB No: IECH/2013/Dec18-006). All patients were Indian residents from the states of Tamil Nadu, West Bengal, Andhra Pradesh, Manipur, and Pondicherry.

\section{DNA extraction}

DNA from 55 tumor samples was extracted by a high salt method. The tumor tissue was processed by grinding the fresh sample using a motor and pestle in liquid nitrogen. For protease digestion, the tissue was transferred into a microfuge tube containing $1 \mathrm{ml}$ of Tris Nacl EDTA SDS (10 $\mathrm{mM}$ Tris, $6 \mathrm{M} \mathrm{NaCl}, 100 \mathrm{mM}$ ethylenediaminetetraacetic acid, and $0.6 \%$ sodium dodecyl sulfate) buffer with $60 \mu \mathrm{l}$ of proteinase- $\mathrm{k}(20 \mathrm{mg} / \mathrm{ml})$ and the tubes were incubated overnight at $45^{\circ} \mathrm{C}$. At the end of the incubation period, $277 \mu \mathrm{l}$ of $6 \mathrm{M} \mathrm{NaCl}$ was added, mixed, and centrifuged for 12,000 RPM for $10 \mathrm{~min}$. The supernatant was transferred to a fresh microfuge tube, and DNA was precipitated by adding equal volume of $100 \%$ ethanol. The DNA was pelleted by centrifugation at 12,000 RPM for $10 \mathrm{~min}$. After centrifugation, the supernatant was discarded and the pellet was washed with $70 \%$ ethanol and air-dried. The recovered DNA was suspended in 20-100 $\mu$ l of sterile distilled water. The DNA was quantitated by using NanoDrop instrument (Thermo Fisher scientific) and quality of the DNA was tested on agarose gel electrophoresis.

Polymerase chain reaction-restriction fragment length polymorphism

Polymerase chain reaction (PCR) amplification of $p 53$ gene at codon 248 was performed in $50 \mu$ l of reaction mixture containing $5 \mu \mathrm{l}$ of $10 \mathrm{x}$ buffer, $2 \mu \mathrm{l}$ of each primer, $4 \mu \mathrm{l}$ of dNTP mixture $(2.5 \mathrm{mM}), 0.4 \mu \mathrm{l}$ of Taq polymerase (5units/ml) (Takara, Japan), $1 \mu l$ of template DNA (50 ng/ $\mu \mathrm{L})$, and $35.6 \mu \mathrm{l}$ of $\mathrm{H}_{2} \mathrm{O}$. The profile used in the PCR (Eppendorf Master cycler Nexus cycler) was $30 \mathrm{~s}$ at $94^{\circ} \mathrm{C}, 45 \mathrm{~s}$ at $68^{\circ} \mathrm{C}, 72^{\circ} \mathrm{C}$ for $50 \mathrm{~s}$ for 35 cycles, and 5 min at $72^{\circ} \mathrm{C}$. The PCR product was digested with Msp1 restriction enzyme (New England Biolabs) and the digested products were visualized under ultraviolet light on the gel documentation system (Syngene) after electrophoresis on a $2 \%$ agarose gel containing ethidium bromide. The primers used was Forward: 5'TGG TGC TGG GCA CCT GTA GTC CCA GCT ACT CG3' and Reverse: 5' ACT ACT CAG GAT AGG AAA AGA GAA GCA AGA GGC3'.[11]

\section{Results}

p53 mutation using polymerase chain reactionrestriction fragment length polymorphism

p53 mutation detection was assessed for 55 samples using PCR-restriction fragment length polymorphism (PCR-RFLP) method. For determining the mutations in the codon 248, PCR-amplified fragments of $p 53$ gene (680 base pair) were digested with restriction enzyme $M s p 1$ for $1 \mathrm{~h}$ at $37^{\circ} \mathrm{C}$ and electrophoresed in $2 \%$ agarose gel containing ethidium bromide. Upon restriction, the wild type resulted in 170, 220, and 290 base pair product for the CGG (R/R) in codon 248. Samples with 170, 220, 290, and 460 base pairs represent the heterozygous mutation (HTM) since the CGG (Arg) codon gets mutated to TGG (Trp) or other sequences. The p53 mutational analysis in all 55 samples is shown in Figure 1. Of 55 samples, only one HTM was observed. The p53 mutation rate in a total of 55 samples was $98 \%(54 / 55)$

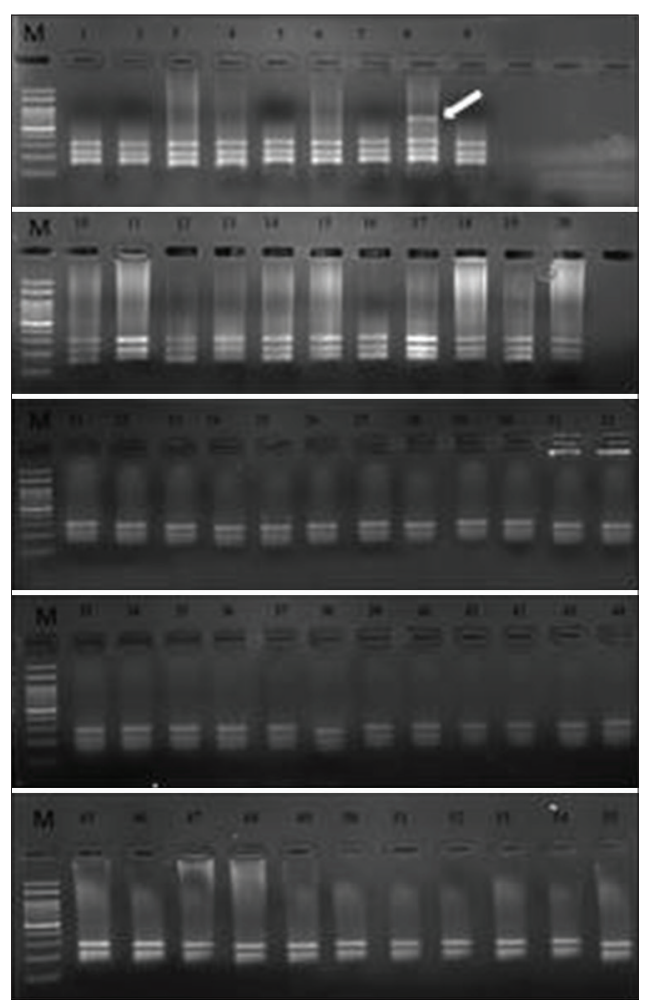

Figure 1: Mutational analysis of $p 53$ gene at codon 248 by polymerase chain reaction-restriction fragment length polymorphism in all the 55 samples. $M=$ Molecular weight marker of $100 \mathrm{bp}$. Lane 1-7 and 9-55 = Wild type and Lane 8 = heterozygous mutant (indicated by an arrow) 
wild type and $2 \%(1 / 55)$ was heterozygous. Differences in the categorical variables including age, gender, anatomical location of the tumor, stage, histopathology, grade, tobacco usage, and treatment type between patients with and without p53 mutations were evaluated. The p53 mutations and the clinicopathological factors of all the patients are shown in Table 1.

\section{Discussion}

Our laboratory has been interested in identification of mutations in various genes of HNSCC patients using DNA isolated from the tumor samples. ${ }^{[12-14]}$ Most of the properties of cancer can be related to mutations in the genome. p53 protein is one of the essential proteins required for maintaining the integrity of genome by

Table 1: p53 mutations and clinicopathological factors of all head-and-neck cancer patients used in this study

\begin{tabular}{|c|c|c|c|}
\hline & $\begin{array}{c}\text { Total } \\
(n=55)\end{array}$ & $\begin{array}{c}\text { WT } \\
(n=54)\end{array}$ & $\begin{array}{l}\text { HTM } \\
(n=1)\end{array}$ \\
\hline \multicolumn{4}{|l|}{ Age (years) } \\
\hline$<45$ & $25(45.5)$ & $41(76)$ & $1(100)$ \\
\hline$>45$ & $30(54.5)$ & $13(24)$ & 0 \\
\hline \multicolumn{4}{|l|}{ Gender } \\
\hline Male & $50(91)$ & $51(94)$ & $1(100)$ \\
\hline Female & $5(9)$ & $3(6)$ & 0 \\
\hline \multicolumn{4}{|l|}{ Diagnosis } \\
\hline Oral cavity & $47(85.5)$ & $42(78)$ & 0 \\
\hline Oropharynx & $2(3.5)$ & $4(7)$ & $1(100)$ \\
\hline Hypopharynx & $1(2)$ & $5(9)$ & 0 \\
\hline Larynx & $1(2)$ & $3(6)$ & 0 \\
\hline Others & $4(7)$ & 0 & 0 \\
\hline \multicolumn{4}{|l|}{ Stage } \\
\hline Stage I & $8(14.5)$ & $4(7)$ & 0 \\
\hline Stage II & 0 & $31(57)$ & 0 \\
\hline Stage III & $14(25.5)$ & $16(30)$ & 0 \\
\hline Stage IV a & $21(38)$ & $3(6)$ & $1(100)$ \\
\hline Stage IV b & $10(18)$ & 0 & 0 \\
\hline Stage IV c & $2(4)$ & 0 & 0 \\
\hline \multicolumn{4}{|l|}{ Histopathology report } \\
\hline Squamous cell carcinoma & $54(98)$ & $49(91)$ & $1(100)$ \\
\hline Adenocarcinoma & $1(2)$ & $5(9)$ & 0 \\
\hline Others & 0 & 0 & 0 \\
\hline \multicolumn{4}{|l|}{ Grade } \\
\hline Grade I & $8(14)$ & $19(35)$ & $1(100)$ \\
\hline Grade II & $45(82)$ & $35(65)$ & 0 \\
\hline Grade III & $2(4)$ & 0 & 0 \\
\hline \multicolumn{4}{|l|}{ Tobacco usage } \\
\hline Yes & $42(76)$ & $48(89)$ & $1(100)$ \\
\hline No & $13(24)$ & $6(11)$ & 0 \\
\hline \multicolumn{4}{|l|}{ Treatment type } \\
\hline Radical surgery & $2(3.3)$ & $53(98)$ & 0 \\
\hline Surgery + post-OP RT & $51(93.4)$ & $1(2)$ & $1(100)$ \\
\hline Radical RT & $2(3.3)$ & 0 & 0 \\
\hline
\end{tabular}

preventing proliferation of cells when the genomic DNA is mutated. Mutation in p53 will lead to production of cancer cells with high rate of somatic mutations in the tumor. ${ }^{[3]}$ For these reasons, monitoring mutations in the $p 53$ gene in cancer patients is of interest. Several mutations are reported in p53 gene in various cancers; among this, $\mathrm{R} 248 \mathrm{~W}$ is one of the common mutations. ${ }^{[15]}$ Considering these factors, using PCR-RFLP technique, R248W mutations in p53 gene were screened in 55 HNSCC patients.

From the results, it was interesting to note that, of 55 samples analyzed in this study, there was only one heterozygous R248W mutation, suggesting that R248W mutation is not prevalent in HNSCC patients of Indian origin. In Chinese population also, of 35 patients with HNSCC, only two mutations were detected in p53 gene at codon 248. ${ }^{[16]}$ Similar studies carried out with American population of HNSCC patients also reveal a lower percentage $(3.5 \%)$ of $\mathrm{R} 248 \mathrm{~W}$ mutation. ${ }^{[3]}$ Depending on the type of cancer, the site of mutations also differs; hence, studies directed toward identification of mutations in the whole p53 coding sequence will give the complete status of p53 mutations in these patients. Furthermore, similar studies carried out with more patients representing other parts of India should give us more details about the status of R248 mutations in Indian HNSCC patients.

\section{Conclusion}

Identification of mutations in cancer patients will give an insight into molecular mechanism behind the cause of the disease, and also the correlation of the mutation to patient's disease progression, response to treatment, and recurrence of the disease will help the clinicians to design novel and effective treatment protocols to the cancer patients as well as these data can be used for preclinical counseling for individuals having deleterious germ line mutations. In this study, we screened for one of the widely reported mutations in p53 gene, $\mathrm{R} 248 \mathrm{~W}$, and report that this mutation is less prevalent in HNSCC patients of Indian origin.

\section{Financial support and sponsorship}

This study was financially supported by Vellore Institute of Technology - VIT seed grant (12927).

\section{Conflicts of interest}

There are no conflicts of interest.

\section{References}

1. Kamangar F, Dores GM, Anderson WF. Patterns of cancer incidence, mortality, and prevalence across five continents: Defining priorities to reduce cancer disparities in different geographic regions of the world. J Clin Oncol 2006;24:2137-50.

2. Rebecca LS, Kimberly DM, Ahmedin J. Cancer Statistics. Ca Cancer J Clin 2017;70:7-30.

3. Ge Z, Zhiyi L, Jeffrey NM. TP53 mutations in head and neck squamous cell carcinoma and their impact on disease progression and treatment response. J Cell Biochem 2016;117:2682-92. 
4. David PL, Sam B. p53: Oncogene or anti-oncogene. Genes Develop 1990;4:1-8.

5. Levine AJ, Perry ME, Chang A, Silver A, Dittmer D, Wu M, Welsh D. The 1993 walter hubert lecture: The role of the p53 tumour-suppressor gene in tumorigenesis. $\mathrm{Br} \mathrm{J}$ Cancer 1994;69:409-16.

6. Hollstein M, Sidransky D, Vogelstein B, Harris CC. p53 mutations in human cancers. Science 1991;253:49-53.

7. Field JK, Pavelic ZP, Spandidos DA, Stambrook PJ, Jones AS, Gluckman JL. The role of the p53 tumor suppressor gene in squamous cell carcinoma of the head and neck. Arch Otolaryngol Head Neck Surg 1993;119:1118-22.

8. Olivier M, Hollstein M, Hainaut P. TP53 mutations in human cancers: Origins, consequences, and clinical use. Cold Spring Harb Perspect Biol 2010;2:a001008.

9. Cancer Genome Atlas Network. Comprehensive genomic characterization of head and neck squamous cell carcinomas. Nature 2015;517:576-82

10. Caamano J, Zhang SY, Rosvold EA, Bauer B, Klein-Szanto AJP. p53 Alterations in human squamous cell carcinomas and carcinoma cell lines. Am J Pathol 1993;142:1131-9.
11. Liming O, Chongtao G, Haizhen W, Suxia L, Huizhan Z. PCR-RFLP to detect codon 248 mutation in exon 7 of p53 tumor suppressor gene. Biochem Molecular Biol Educ 2009;37:106-9.

12. Abarna R, Dutta D, Sneha P, George P, Anbalagan M. Identification of novel heterozygous Apex 1 gene variant (Glu87Gln) in patients with head and neck cancer of Indian origin. J Cell Biochem 2018;119:8851-61.

13. Debnarayan D, Rajadurai A, Mehatre S, Kannan S, Sriprakash D, Rayappa C, et al. Effect of Arg399Gln single-nucleotide polymorphism in XRCC1 gene on survival rate of Indian squamous cell head-and-neck cancer patients. J Cancer Res 2018;20:1-8.

14. Ashna G, Moorthy A. High incidence of BRAF V600 mutation in Indian patients with head and neck cancer. Front Biosci 2018;10:520-7.

15. Cara LB, Honnavara NA. p53 and the pathogenesis of skin cancer. Toxicol Appl Pharmacol 2007;224:241-8.

16. Shi Q, Xiao K, Wei W, Zhang BY, Chen $\mathrm{C}, \mathrm{Xu} \mathrm{Y}$, et al. Associations of TP53 mutations, codon 72 polymorphism and human papillomavirus in head and neck squamous cell carcinoma patients. Oncol Rep 2013;30:2811-9. 